\title{
PERHITUNGAN TELUR TOXOCARA CATI DAN JUMLAH SEL DARAH PUTIH PADA KUCING LIAR (Felis catus) DI DUKUH KUPANG SURABAYA
}

\author{
Roeswandono ${ }^{1}$, Olan Rahayu Puji Astuti Mussa ${ }^{1}$, Micco Joshua Apriano Pangaribuan ${ }^{1}$ \\ Bagus Uda Palgunadi ${ }^{*}$ \\ ${ }^{1}$ Fakultas Kedokteran Hewan, Universitas Wijaya Kusuma Surabaya \\ *Email: udapalgunadi@yahoo.com
}

\begin{abstract}
The research aimed to know the degree of infection from egg calculated and increased numbers of white blood cells (eosinophils and lymphocytes) in wild cats (Felis catus). The samples of the research as many as 30 wild cats around the Around of Dukuh Kupang Surabaya. The examination was done by Mc Master method with 100x magnification and the calculated of white blood cells (eosinophil and lymphocytes). The results showed the degree of toxocariasis infection in wild cats (Felis catus) in Surabaya in Dukuh Kupang was seen from the average value of the 468.3 egg examination and the calculated of white blood cells (eosinophilic and lymphocytes) with an average value of eosinophilic $0.73 \times 103 / \mu l$ and lymphocytes $10.72 \times 103 / \mu l$. This study used descriptive method. Toxocariasis infection was included in the degree of moderate infection in wild cats (Felis catus) in Dukuh Kupang Surabaya with moderate degree.
\end{abstract}

Keywords: Toxocariasis, degree of infection, wild cats (Felis catus), Eosinophil, lymphocytes

\section{PENDAHULUAN}

Dukuh kupang merupakan sebuah kelurahan di wilayah Kecamatan Dukuh Pakis Kota Surabaya Provinsi Jawa Timur. Kecamatan Dukuh Pakis terbagi menjadi empat kelurahan terdiri dari Kelurahan Dukuh Kupang, Kelurahan Dukuh Pakis, Kelurahan Gunung Sari dan Kelurahan Pradah Kalikendal (BMKG, 2015). Seiring dengan perkembangan zaman, jumlah populasi kucing liar di kelurahan Dukuh Kupang tampak meningkat. Kucing merupakan hewan kesayangan dalm kehidupan manusia.

Manusia telah memelihara kucing sejak ribuan tahun yang lalu melalui proses domestikasi. Kucing memiliki hubungan yang erat dengan manusia karena sifat kucing yang mudah dipelihara dan mudah menyesuaikan diri. Saat ini kucing dipelihara tidak hanya sebagai hobi namun telah menjadi gaya hidup. Kucing dapat berperan dalam penyebaran berbagai jenis penyakit parasit termasuk cacing (Sardjono 2017).

Kucing yang dipelihara tidak terlepas dari penyakit infeksius, salah satunya adalah penyakit parasit yang bisa menginfeksi kucing adalah infeksi cacing Toxocara cati yang menyerang anak kucing dan kucing dewasa (Estuningsih, 2005). Infeksi dari Toxocara cati dapat menimbulkan masalah bagi kesehatan manusia karena Toxocara cati bersifat zoonosis, kejadian dari toxocariasis sering sering menyerang anak-anak karena bermain di pasir atau tanah yang sudah terdapat telur infektif dari Toxocara cati (Magnaval et al, 2001).

Manusia dapat tertular toksokariasis melalui termakan telur infektif yang terdapat dalam feses kucing dan tanah terkontaminasi. Toksokariasis pada manusia menyebabkan viceral larva migrans (VLM) dan ocular larva migran (OLM) (Gillespie, 2006). Pada manusia, larva tersebut dapat mencapai otak sehingga dapat menimbulkan gangguan yang sangat berat pada anak-anak maupun pada dewasa.

Visceral larva migrans dapat menyebabkan pembengkakan organ tubuh atau sistem saraf pusat. Organ yang dapat terserang antara lain hati, paru-paru, ginjal, dan otak sedangkan pada OLM terjadi saat larva memasuki mata, menyebabkan inflamasi dan pembentukan jaringan ikat pada retina. Kelukaan pada chamber bola mata menyebabkan granulomatous renitis, perlekatan retina, kehilangan daya lihat, atau pada kasus berat kebutaan pemanen (Gillespie, 2006).

Faktor yang bisa mempengaruhi terhadap kejadian prevalensi infeksi parasit adalah faktor lingkungan dan faktor internal hewan (Nealma,dkk., 2013). Kondisi lingkungan yang sangat berpengaruh terhadap parasit kucing, lingkungan tinggal kucing yang tidak bersih atau kotor memungkinkan adanya cemaran oleh telur infektif Toxocara cati (Guilherme et al, 2013). Berdasarkan studi penelitian yang dilakukan 
Nealma, dkk. (2013), hasil pemeriksaan dari 80 feses kucing di wilayah Denpasar didapatkan 39 positif terinfeksi cacing Toxocara cati atau prevalensinya sebesar $48,8 \%$.

Berdasarkan sistem pemeliharaan, kucing yang dipelihara di wilayah Denpasar didapatkan 13 positif terinfeksi cacing Toxocara cati dari 40 sampel yang terperiksa dengan prevalensi sebesar 32,5\%. Pada kucing liar didapatkan 26 positif terinfeksi cacing $T$. cati dari 40 sampel feses kucing liar yang terperiksa dengan prevalensi sebesar $65 \%$.

Manifestasi klinis penyakit parasit seringkali bersifat umum dengan gejala dan keluhan penderita mirip satu dengan yang lainnya. Oleh karena itu gejala klinis penyakit parasitik tidak selalu dapat dijadikan pegangan untuk menentukan diagnosis penyakit parasitik. Pemeriksaan laboratorium yang tepat sangat di perlukan untuk menegakkan diagnosis laboratorium adalah pasti penyebab penyakitnya (Soedarto, 2009). Diagnosa dengan pemeriksaan feses di yang paling sering dilakukan (Soulsby, 1982).

Kucing yang terinfeksi cacing Toxocara spp memperlihatkan gejala kelemahan umum. Ekspresi muka tampak sayu, mata berair, dan mukosa mata maupun gusi tampak memucat. Hal itu dipicu oleh anemia yang diderita (Subronto, 2006). Sesuai dengan hasil studi penelitian yang dilakukan Resende et al (2015), analisa pada sel darah merah menunjukkan adanya pengurangan jumlah total eritrosit dan level hemoglobin yang sangat signifikan pada hari ke lima pasca infeksi. Sedangkan tingginya limfosit (limfositosis) menandakan penyakit yang berlangsung kronis dan eosinofilia dapat menggambarkan adanya infeksi parasit (Dharmawan, 2002).

Zaman (2014) menyatakan Setelah menelan telur berembrio larva menetas di usus, masuk sirkulasi dan migrasi ke berbagai organ dalam tubuh. Kemudian tidak mencapai dewasa dan keadaan ini dikenal sebagai visceral larva migrans. Kondisi lingkungan sangat mempengaruhi tingginya resiko terinfeksi Toxocara spp.

Dengan mengetahui derajat infeksi Toxocariasis maka dapat diketahui potensi penularan visceral larva migrans antar kucing atau manusia. Mengingat sejauh ini belum ada penelitian mengenai peningkatan sel darah putih (eosinofil dan limfosit) pada kasus Toxocariasis maka dari itu perlu dilakukan penelitian ini. Tujuan dari penelitian ini adalah untuk meningkatkan kewaspadaan terhadap parasit zoonotik dengan mengetahui derajat infeksi cacing Toxocara,spp di Dukuh kupang dan gambaran darah yang terjadi apabila terinfeksi Toxocara sp.

\section{MATERI DAN METODE}

Penelitian dilakukan dengan pengambilan feses dan darah pada kucing liar yang ditangkap dari Kelurahan Dukuh Kupang, Surabaya. Untuk pemeriksaan feses dilakukan di Laboratorium Parasitologi Fakultas Kedokteran Hewan Universitas Wijaya Kusuma di Surabaya dan pemeriksaan darah dilakukan di laboratorium Pacar Surabaya Jl. Karang Menjangan No.18, untuk Sampel yang digunakan dalam penelitian ini adalah 30 ekor kucing liar.

\section{Perhitungan Telur Cacing}

1gram feses dilarutkan dengan $15 \mathrm{ml}$ air, kemudian dihomogenkan. Siapkan double deck glass. Masukkan 0,3 ml gula jenuh dan 0,3 ml larutan tinja ke dalam double deck glass. Aduk dengan menggunakan jarum. Biarkan $3-5$ menit lalu diamati dibawah mikroskop. Lalu dihitung menggunakan rumus:

Telur Cacing per Gram Tinja $=$ N x 50

Keterangan :

$\mathrm{N}=$ Jumlah telur cacing dalam satu double deck glass.

\section{Metode Mc Master}

Metode pengapungan sederhana dilakukan terhadap sampel yang dinyatakan pada metode McMaster, untuk memastikan keberadaan telur cacing. Sampel feses yang telah ditambahkan larutan gula jenuh pada metode Mc Master dituang ke dalam tabung reaksi sampai penuh dan terbentuk miniskus. Gelas penutup diletakan pada ujung tabung reaksi dan didiamkan selama 10 menit, kemudian gelas penutup diambil dan diletakkan pada gelas objek. Pengamatan dilakukan dibawah mikroskop dengan pembesaran 100 kali.

\section{Pengambilan Darah}

Pengambilan darah bisa diambil pada bagian vena Cephalica Antibrachii Anterior pembuluh ini terletak pada bagian distal anterior kaki depan. Proses pengambilan darah adalah sebagai berikut, Rambut di sekitar pembuluh darah 
dicukur bila perlu, Pembuluh darah dibendung pada bagian siku, Setelah darah terbendung, daerah tersebut diusap dengan kapas yang dibasahi alkohol, Tujuannya untuk desinfektan Jarum suntik steril disuntikkan, Setelah jarum masuk, dilakukan aspirasi untuk mengambil darah yang dibutuhkan, Diusapkan kembali kapas yang dibasahi alkohol, Darah dimasukkan kedalam tabung Edta, Sample darah dibawa ke laboratorium Pacar.

\section{Analisa Data}

Analisis data dilakukan secara deskriptif dari hasil perhitungan telur per gram tinja dan peningkatan sel darah putih (eosinofil dan limfosit).

\section{HASIL}

\section{Derajat Infeksi Toxocariasis pada Kucing Liar di Dukuh Kupang}

Hasil pemeriksaan feses terhadap 30 sampel feses kucing liar di Kelurahan Dukuh Kupang menunjukkan bahwa 30 sampel feses dari 25 sampel feses dinyatakan positif. Hasil perhitungan Telur Cacing Per Gram Tinja (TCPGT) dari 30 feses positif cacing Toxocara spp. didapatkan derajat infeksi Toxocariasis sebesar $0-950$ telur cacing per gram tinja dan rata - rata 468,3 yang menggambarkan derajat infeksi Toxocaris pada kucing liar di Kelurahan Dukuh Kupang tergolong sedang. Derajat infeksi terberat yaitu pada angka TCPGT 950. Tabel 1. Derajat infeksi Toxocariasis pada kucing liar di Dukuh Kupang.

\begin{tabular}{ccccc}
\hline $\begin{array}{c}\text { Total } \\
\text { sampel }\end{array}$ & $\begin{array}{c}\text { Total } \\
\text { TCPGT }\end{array}$ & $\begin{array}{c}\text { rata- } \\
\text { rata }\end{array}$ & Std. dev. sampel \\
\cline { 1 - 1 } $\mathbf{3 0}$ & 14050 & 468,33 & 294,9235241 \\
\hline
\end{tabular}

Hasil penelitian yang menunjukkan bahwa kucing di Kelurahan Dukuh Kupang terinfenksi cacing Toxocara,spp dengan derajat sedang dengan rata-rata nilai TTGT 468,3 sesuai dengan standar Menurut Bowman et al. (2002), Jumlah telur tiap gram tinja (TTGT) dapat digunakan sebagai penduga berat atau ringannya derajat infestasi.Infestasi ringan memiliki jumlah TTGT1-199, infestasi sedang memiliki jumlah TTGT200-999 dan infestasi berat memiliki jumlah TTGT $>1.000$, derajat keparahan infestasi tergantung jumlah cacing yang menginfestasi. Keadaan ini memungkinkan terjadi apabila lingkungan (tanah)telah tercemar oleh telur cacing

Toxocara, spp.

Kucing liar dapat terinfeksi T.cati melalui tertelan telur infektif dikarenakan pola hidup yang makan tanpa adanya tempat makan seperti pada kucing rumahan, terkadang makanan yang dikonsumsi kucing liar terkontaminasi dengan tanah yang mengandung telur T.cati Sesuai menurut Hartaningrum (2003) bahwa kucing yang hidupnya tidak terpelihara dengan baik seperti makan dan minum di sembarang tempat serta sanitasi lingkungan yang tidak bersih dapat memudahkan terinfeksi oleh cacing. Selanjutnya menurut (Guilherme et al., 2013) lingkungan yang ideal bagi perkembangbiakan cacingcacing yang ditularkan melalui tanah Transmisi terjadi melalui tertelannya telur T.canis atau T.cati dari anjing dan kucing, dapat juga melalui tanah dan pasir yang sudah terkontaminasi feses dari hewan.

Siklus hidup T. cati dimulai dari stadium infektif yaitu larva stadium ke dua yang berada di dalam telur. mereka menetas di dalam lambung setelah kucing memakan telur tersebut, dan sebagian besar larva berpindah melalui sistem portal hati, hati dan paru paru menuju trakea dan kembali ke lambung kemudian menjadi stadium ke empat, dan kembali ke dalam lumen usus untuk menjadi dewasa (Levine, 1996). Kebanyakan penderita toxocariasis tidak menunjukkan gejala klinis (Camparoto et al,.2008), pada negara tropis penderita toxocariasis dapat dilihat melalui gejala kulit seperti bulu kusam/rontok yang diakibatkan perasit ini (Joob and Wiwanitkit, 2016).

\section{Pengaruh Toxocariasis terhadap peningkatan sel darah putih (Eosinofil dan Limfosit)}

Infeksi Toxocariasis memiliki gambaran yang memungkinkan terjadinya peningkatan pada sel darah putih (Eosinofil dan Limfosit).

Tabel 2. Nilai pemeriksaan sel darah putih

(Eosinofil dan Limfosit).

\begin{tabular}{ccccc}
$\begin{array}{c}\text { jenis } \\
\text { pemeriksa } \\
\text { an }\end{array}$ & $\begin{array}{c}\text { Tot. } \\
\text { samp } \\
\text { el }\end{array}$ & $\begin{array}{c}\text { Total } \\
\left(\mathbf{x 1 0}^{3} / \boldsymbol{\mu}\right. \\
\mathbf{L})\end{array}$ & $\begin{array}{c}\text { rata- } \\
\text { rata } \\
\left(\mathbf{x 1 0}^{3} / \boldsymbol{\mu}\right. \\
\mathbf{L})\end{array}$ & $\begin{array}{c}\text { Std. } \\
\mathbf{d e v} \\
\text { sampe }\end{array}$ \\
\cline { 4 - 5 } eosinofil & 30 & 21,91 & 0,73 & 0,38 \\
\hline limfosit & 30 & 321,8 & 10,72 & 4,7 \\
\hline
\end{tabular}


Data yang diperoleh dari penelitian ini menunjukkan bahwa dari ke 30 sample dengan rata-rata $0,73 \times 10^{3} / \mu \mathrm{L}$ tidak ada yang dinyatakan peningkatan eosinophil atau dalam hal ini normal dan 25 sample dinyatakan adanya peningkatan limfosit dengan nilai rata-rata 10,72 $\mathrm{x} 10^{3} / \mu \mathrm{L}$. Penelitian ini mendapatin hasil eosinophil dalam keadaan normal selanjutnya pada hasil lemfosit didapatin 25 sample dinyatakan adanya peningkatan dari normal. Penilaian tinggi rendahnya dapat dibandingkan menurut Reference Intervals for Hematology values in Domestic Animals (Harvey, 2012) Batasan normal eosinophil kucing (0-1.8 x $\left.10^{3} / \mu \mathrm{L}\right)$ dan normal limfosit kucing $(0,9-5,5 \mathrm{x}$ $\left.10^{3} / \mu \mathrm{L}\right)$.

Dalam penelitian ini hasil pemeriksaan eosinophil masih dalam batas normal jika didapat hasil diatas batas normal maka, Menurut Schalm (2010), peningkatan jumlah eosinofil di dalam sirkulasi darah diatas nilai interval normal disebut sebagai eosinofilia. Eosinofilia bisa terjadi karena meningkatnya produksi dalam sumsum tulang, meningkatnya pelepasan cadangan dari sumsum tulang, redistribusi selsel dari pool marginal, daya hidup intravaskuler diperpanjang. Beberapa kausa eosinofilia diantaranya adalah penyakit parasitik (ektoparasit, endoparasit) dan respons alergik (alergen).

Sebaliknya, kondisi menurunnya jumlah eosinofil dalam sirkulasi di bawah nilai interval normal disebut sebagai eosinopenia. Eosinopenia terjadi karena menurunnya pelepasan dari sumsum tulang, adanya lisis intravaskuler, meningkatnya migrasi ke dalam jaringan. Kondisi eosinopenia biasa terlihat pada stres leukogram. Namun demikian, relevansi klinis keadaan eosinopenia sangat sedikit (Stockham \& Scott 2008).

Sedangkan dalam pemeriksaan limfosit dadapati hasil peningkatan diatas batas normal maka dapat disebut limfositosi, Limfositosis merupakan keadaan dimana jumlah limfosit di dalam sirkulasi darah meningkat diatas nilai interval normal. Peningkatan jumlah limfosit dapat terjadi pada kondisi fisiologis maupun patologis. Kausa limfositosis fisiologis meliputi exercise, stres fisik maupun emosi, excitement (pada kucing), dan kondisi takut (Jain 1993). Terjadi limfositosis patologis akibat adanya, stimulasi antigenik (misalnya peradangan kronis, vaksinasi). Gambaran umum limfositosis patologis merupakan penyakit inflamasi yang bersifat kronis. Biasanya disertai pula dengan neutrofilia dan monositosis (Stockham and Scott 2008).

\section{KESIMPULAN}

Derajat infeksi Toxocariasis pada kucing liar di Dukuh Kupang adalah Sedang dan Pada pemeriksaan sel darah putih (Eosinofil dan Limfosit) hanya didapatin nilai eosinophil yang normal dan limfosit 25 sample dengan nilai diatas batas normal.

\section{REFERENSI}

Badan Meteorologi, Klimatologi dan Geofisika. 2015. Stasiun Geofisika Kota Surabaya Bowman, D.D., C.M. Hendrix, D.S. Lindsay and S.C. Barr. 2002. Feline Clinical Parasitology. 1st ed. Iowa State University Press. Iowa. 281.

Bijanti R, Yuliati M.G.A, Wahjuni R.S, Utomo R.B. 2010. Buku Ajar Patologi Klinik Veteriner. Cetakan Pertama. Surabaya(ID): Pusat Penerbit dan Pecetakan Unair.

Camparoto, M.L., B. Fulan, C.M. Colli, M.L. paludo, A.L.F. Guilherme, and M.A. Fernandez. 2008. Initial stage of development and migratory behavior of Toxocara canis larvae in BALB/c mouse experimental model. Gene Mol Res, 7(2): 444-450.

Cardillo, N., I. Sommerfelt., F. Fariña., M. Pasqualetti., M. Pérez., M. Ercole., A. Rosa and M. Ribicich. 2014. A Toxocara cati eggs concentration method from cats faeces, for experimental and diagnostic purposes. Elsevier. 144: 73.

Dharmawan NS. 2002. Pengantar Patologi Klinik Veteriner. Denpasar: Udayana Press. Estuningsih, S.E. 2005. Toxocariasis Pada Hewan dan Bahayanya Pada Manusia.J Wartazoa 15 (3): 136-142.

Fan, C.K., C.W. Liao and Y.C. Cheng. 2013. Factors affecting disease manifestation of toxocarosis in humans: Genetics and environment. J. Vetpar. 193: 342 - 352.

Gallas, M. and E. F. Silveira. 2013. Toxocara cati ( Schrank, 1788 ) (Nematoda, Ascarididae) in different wild feline species inBrazil: new host records. Revista Biotemas. 26 (3): 119 - 121.

Gillespie, T.R. 2006. Noninvasive assessment of gastrointestinal parasite infections in free 
ranging primates. J. Primatol. 27:11291143.

Guilherme E.V, A.A. Marchioro, S.M. Arauju, D.L.M. Falavigna, C. Adamai, G.F. Guilherme, G.R. Elefant, A.L.F. guilhere. 2013. Toxocariasis In Children Attending A Public Health Service Pneumology In Parana Atata, Brazil. Rev Inst Med Trop Sao Paulo, 55(3): 189-192.

Hartaningrum, B.D. (2003). Identifikasi Cacing Pita pada Saluran Pencernaan Kucing Lokal dari Beberapa Lokasi Di Bali. S.KH. Skripsi, Fakultas Kedokteran Hewan. Universitas Udayana. Denpasar.

Hodgkins, E.M. 2008. Your Cat: Simple new secret to a longer, stronger life. Thomas dunne books. New york. $24-25$.

Huidekoper, R.S., K. Wilson and I.M. Mellen. 2011. The Anatomy of the Cat: A Collection of Historical Articles on Feline Physiology. British Library Cataloguing-in-Publication Data UK. 24 - 25.

Jain NC. 1993. Essential of Veterinary Hematology. Philadelphia: Lea \& Febiger.

John W.H 2012. Veterinary Hematology A Diagnostic Guide and Color Atlas. 3251 Riverport St. Louis, Missouri 63043. Peg 329.

Joob, B., and V. Wiwanitkit. 2016. Toxocara canis and Chronic Urticaria. Iran J Allergy Asthma Immunol, 15(2): 166.

Levine, N.D. 1996. Parasitologi Veteriner. Gadjah mada university press. Yogyakarta.

Linnaeus, C. 1758. Systema Naturae per regna tria naturae, secundum classis, ordines, genera, species cum characteribus, differentiis, synonymis, locis. $10^{\text {th }}$ edition, vol. 1. Holmiae: Laurentii Salvii. 62.

Magnaval J.F, L.T Glickman P Dorchies, and B Morrasin. 2001. Highlight of HumanToxicariassis.Korean J parasitol, 39(1): 1-11.

Mehta A.B, Hoffbrand A.V. 2014, Haematology at $a$ Glance.Fourth Edition. London(UK):Wiley-Blackwell

Mikaeili, F., H. Mirhendi, M. Hosseini, Q. Asgari, and E.B. Kia. 2013. Toxocara nematodes in stray cats from Shiraz, southern Iran: intensity of infection and molecular identification of the isolates. Iran J. Parasitol. 8(4): 593600.

Nealma, S., I. M. Dwinata. dan I. B. Made oka. 2013. Prevalensi Infeksi Cacing Toxocara cati pada Kucing Lokal di Wilayah
Denpasar. Indonesia Medicus Veterinus. 2(4): $432-434$.

Playfair J.H.L, Chain B.M. 2009. At a Glance Imunologi.Ninth Edition. London (UK): Blackwell.

Resende, N.M., P.H. Guimarães, F.S. Barbosa, L.M. Oliveira, D.S. Nogueira, A.C. Guimarães, M.T. P. Gonçalves, C.C.O. Amorim, F.M.S. Oliveira, M.V. Caliari, M.A. Rachid, G.T. Volpato, L.L. Bueno, S.M. Geiger and R.T. Fujiwara. 2015. New insights into the immunopathology of early Toxocara canis infection in mice. J. Par Vec. 8:354.

Sardjono TW. 2017. Hematologi Kedokteran dan Veteriner. Malang (ID): UB Press.

Santos, S.V., S.Z. Lescano, J.M. Castro and P.P. Chieffi. 2009. Larval recovery of

Toxocara cati in experimentally infected Rattus norvegicus and analysis of the rat as potential reservoir for ascarid this. Mem Inst Oswaldo Cruz. 104(6): 933 - 934.

Schalm OW. 2010. Veterinary Hematology.Ed ke-6. USA: Wiley-Blackwell.

Shree, V.M, T. Vithya, P. Shankar, R.R.H. Shobha. 2016. A Study on Blood and Blood Components Transfusion, Adverse Reaction at a Tertiary Care Teaching Hospital, Bangalore. J Blood Disord Transfus. 7.

Soulsby, E.J.L. 1982. Helminths, Arthropods and Protozoa of Domesticated Animals. Academic Press. New York.

Soedarto. 2009. Pengobatan penyakit parasit : Amubiasis, Malaria, Cacing Tambang, Filariasis dan Penyakit Parasit lainnya. CV Sagung seto. Jakarta. 1 - 3.

Stockham, S.L. and Scott, M.A. 2008. Fundamentals of veterinary clinical pathology. Blackwell.

Storer, I.T., R.L. Usinger, R.C. Stebbins and J.W. Nybakken. 1972. General Zoology. $5^{\text {th }}$ ed. Mcgraw-hill bookcompany. New York. St. Louis. San Fransisco. 781-782.

Subronto. 2006. Infeksi Parasit dan Mikroba pada Anjing dan Kucing. Gadjah Mada University Press. Yogyakarta.

Woodhall, D.M. and A. E. Fiore. 2013. Toxocariasis: A Review for Pediatricians. In: Journal of the Pediatric Infectious Diseases Society. 3(2): 154. 
pISSN 2460-9773; eISSN 2685-8894

Jurnal Vitek Bidang Kedokteran Hewan Vol.9, November 2019

Zaman, V. 2014. Atlas Parasitologi Kedokteran :Atlas Protozoa, Cacing, dan Athropoda penting. Hipokrates. Jakarta. 201.

Zibaei, M. and S.M. Sadjjadi. 2017. Trend of toxocariasis in Iran: a review on human and animal dimensions. Iranian Journal of Veterinary Research. 18(4): 233-242. 